\title{
Bybel lees vir dag en tyd
}

\section{Book title:}

'n Bril vir Bybel lees ... en vir die lewe

\section{Book Cover:}

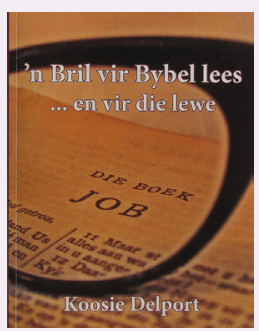

Author:

K. Delport

ISBN:

978-0-620-50098-2

Publisher:

Mybook, 2011, R100.00

*Book price at time of review

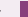

Review title:

Bybel lees vir dag en tyd

Reviewer:

Pieter H. Heystek ${ }^{1}$

\section{Affiliation:}

${ }^{1}$ Reformed Church, PretoriaMontanapoort

Email:

drpieter@montanapoort.co.za

Postal address:

PO Box 1687, Montanapark

0159, South Africa

How to cite this book review: Heystek, P.H., 2013, 'Bybel lees vir dag en tyd', In die Skriflig/In Luce Verbi 47(1), Art. \#177, 1 page. http://dx.doi.org/10.4102/ ids.v47i1.177

\section{Copyright:}

(C) 2013. The Authors.

Licensee: AOSIS

OpenJournals. This work

is licensed under the

Creative Commons

Attribution License.

Read online:

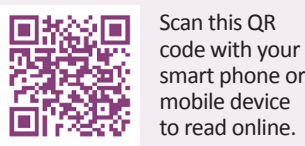

Delport poog om 'n 'bril' vir Bybel lees te ontwerp. In tien hoofstukke verduidelik die skrywer hoe 'n leesbril saamgestel kan word. In hoofstuk 11 word met die bril na die res van die Skrif gegaan en word Delport se hermeneutiese bril van toepassing gemaak op onder andere Psalm 23, 137; 1 Samuel 15; Handelinge 5:1-11; 1 Korintiërs 11:2-16 en Filippense 1:27-2:4. In hoofstuk 12 skryf Delport oor 'Sommige vrae waarmee die leesbril ons laat.' Hy stel dit duidelik dat die Jobbril nie onfeilbaar is nie, alhoewel dit moontlike maar nie finale antwoorde gee nie.

Die outeur ontwerp 'n leesmetode, 'n Bybelkode waardeur die Bybel verstaan kan word. Delport noem dit die Job-bril of die Job-kode. Hy is van mening dat daar baie mense is wat net so deurmekaar voel oor die Bybel soos hy. In 'n moeilik verstaanbare uiteensetting van die boek Job meen die outeur dat die Job-bril uit minstens een algemene vraag en drie spesifieke vrae bestaan.

Die algemene vraag is naamlik waarom die Here hierdie gedeelte in die Bybel laat opneem het. Die spesifieke Job-vrae is die volgende:

- Wat sê hierdie gedeelte oor die Here?

- Wat sê hierdie gedeelte oor die gelowige of die mens of menslikheid?

- Wat sê hierdie gedeelte oor verhoudings?

Die motief vir die skryf van hierdie boek is verstaanbaar, maar die meriete van die Job-bril is myns insiens moeilik verantwoordbaar. Die ontwerp van die Job-kode is moeilik in die hoofstukke volgbaar. Die gebruik van baie subopskrifte in byna elke hoofstuk het tot gevolg dat 'n mens die denklyn van Delport moeilik volg. Denkspronge maak dit verder moeilik om die logiese opbou in die ontwerp van die Job-kode te volg. Die meriete van die boek kom hierdeur in die gedrang. Die feit dat Skrifverklaring ten diepste genadewerk is, asook die grondbeginsel van 'sacra scriptura sui ipsius interpres' word nie na behore aangespreek nie. Die eerste vereiste by die verklaring van die Skrif, naamlik dat die Skrif vir homself moet praat, word ook nie direk verreken nie. Die Skrif moet as geheel benader word en daarom moet Skrif met Skrif verklaar word, eerder as deur 'n spesifieke 'bril' of 'kode'.

Die boek word aanbeveel vir lesers wat vakwetenskaplik in die Hermeneutiek belangstel. 